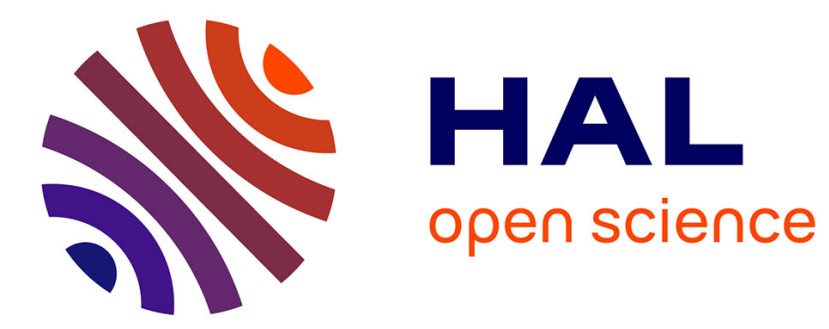

\title{
Grammatical borrowing in Purepecha
}

Claudine Chamoreau

\section{To cite this version:}

Claudine Chamoreau. Grammatical borrowing in Purepecha. Yaron Matras, Jeanette Sakel. Grammatical borrowing in cross-linguistic perspective, Mouton de Gruyter, pp.465-480, 2007. halshs00293374

\section{HAL Id: halshs-00293374 \\ https://shs.hal.science/halshs-00293374}

Submitted on 4 Jul 2008

HAL is a multi-disciplinary open access archive for the deposit and dissemination of scientific research documents, whether they are published or not. The documents may come from teaching and research institutions in France or abroad, or from public or private research centers.
L'archive ouverte pluridisciplinaire HAL, est destinée au dépôt et à la diffusion de documents scientifiques de niveau recherche, publiés ou non, émanant des établissements d'enseignement et de recherche français ou étrangers, des laboratoires publics ou privés. 


\title{
Purepecha
}

\author{
Claudine Chamoreau \\ CELIA (CNRS-IRD-INALCO-PARIS VII) \\ \& CIESAS-Mexico \\ [claudine@vjf.cnrs.fr]
}

\section{Background}

Purepecha (p'orhépecha o tarascan) is classified as an isolated language, spoken by around 110,000 people (10\% of them monolingual), in the state of Michoacan, in the west of Mexico. Spanish was introduced in the $16^{\text {th }}$ century, and became the official language of Mexico, where more than about a hundred languages are still spoken. It gained more importance with the linguistic policies of the Mexican Independence and Revolution, in the $19^{\text {th }}$ and in the $20^{\text {th }}$ centuries respectively. Spanish functions as a prestigious language, and is connected to education, a better standard of living, oral and written media, religion, administration, commerce, and employment.

Nevertheless, Purepecha, in 2003, acquired (like the other indigenous languages spoken in Mexico) the status of official language. In general, Purepecha is used only orally; it having been established as a written language very recently, and only used in that mode by a few individuals (specifically, the intellectual-speakers or the teachers). The language is spoken by $28 \%$ of the Purepecha children aged between 5 and 14, this data indicating that Purepecha is not generally transmitted to the younger generation, who prefer to learn and use Spanish. Moreover, the situation is not homogeneous in all the communities. In some villages, the language functions for communication among all family members and friends (salutations and discussions at home, in the streets, in the shops or markets, and in children's games). In other communities, only the middle-aged and older people speak Purepecha.

Spanish has been the principal contact language for many centuries, however, before the Conquest, there were speakers of other languages in the area - mostly Nahuatl (Uto-Aztecan family), and Otomi (Otopamean family). The influences of these languages in Purepecha has not been studied in detail, but one hypothesis has been proffered regarding constituent order. Purepecha exhibits all the traits of an SOV language: a) tense, aspect and modal markers follow the verb, b) postpositions, c) suffixes almost exclusively, d) case markers, e) main verbs precede 
inflected auxiliaries, f) genitives can precede the head noun, and g) relative clause can precede the head noun. Nevertheless, in the Lake Patzcuaro area, Purepecha has become SVO (Capistran 2002). This order has been attested since the $16^{\text {th }}$ century, and has become progressively more widespread since that time (Villavicencio 2006). Considering that Nahuatl - and Otomi- present a verb-initial structure, this change probably has its roots in areal contact prior to the $16^{\text {th }}$ century, with the subsequent influence of Spanish, an SVO language, continuing the process.

In the present chapter, I will concentrate on the influence of Spanish contact on Purepecha, specifically, on the grammatical structure. related to this contact are found in the areas of phonology, morphological typology, nominal and verbal structures, other parts of speech, constituent order, and syntax. This paper deals with the dialect of Jaracuaro (denoted Jr), a peninsula in Lake Patzcuaro, however, when necessary, I use data from other varieties. Purepecha varieties are more or less mutually intelligible, nevertheless, great sociolinguistic differences exist between them (Chamoreau 2005). Most of the data considered for this paper are the result of my own field research projects carried out over a period of fifteen years.

\section{Phonology}

In the phonological system of Purepecha, two phonemes - that are not shared with Spanish - have been influenced by Spanish: the retroflex $/ \mathfrak{l} /$, a consonant, and the high central vowel / $\mathbf{i} /$. In some varieties (for example, Cuanajo), Purepecha has a phonological opposition between the retroflex $/ \mathrm{r} /$ and the flap /r/ (e.g. jurani 'to make somebody cough'/ ju rani 'to come'), however, in certain varieties, this opposition no longer exists; the retroflex becomes either a flap, losing the retroflex/flap opposition, or a lateral, a phoneme probably borrowed from Spanish. Purepecha conserves an opposition, but shows a new lateral/flap feature. In general, the lateral only appears in Spanish loanwords such as azuli 'blue' (from Spanish 'azul'), or limoni 'lemon' (from Spanish 'limon'). However, in some varieties (for example, Comachuen, Arantepacua), young and middle-aged speakers use the lateral (jolempiri 'teacher'), while the older generation uses the flap (jorempiri), or the retroflex (jotempiri). The use of the lateral in Purepecha words reveals the replacement of the Purepecha phoneme by the Spanish phoneme. Currently, Purepecha is acquiring a new phonological opposition (Chamoreau 2002a).

The high central vowel /it/ is used after /ts/, /tsh/ and $/ \delta /$, and a phonological opposition appears between /i/ and the high front vowel /i/ 
(e.g. tsiriri 'rib'/ tsiriri 'paste'; khefi 'shoulder'/ khaji 'shape'). Nevertheless, particularly in the varieties which have lost the retroflex $/ \mathfrak{r} /$, and have transferred the lateral $/ 1 /$, and in other varieties, in the case of the young and middle speakers, the high central vowel / $\mathbf{i} /$ is no longer used, and /i/ replaces /it/ (tsiriri 'paste', khafi 'shape'). The phonological system of these varieties has lost a vowel, and, accordingly, presents the same vowel system as Spanish (/i/, /u/, /e/, /o/, /a/).

\section{Morphological Typology}

Purepecha has not undergone an important re-structuring of its typological profile. It is an agglutinative and synthetic language that comprises a very elaborated derivational verbal system. For example, for the passive, the verb presents a derivational verbal suffix $n a$ (1), and in order to express the equational constructions (2) the $e$ suffix is used. In certain varieties, the suffix is $i$ :

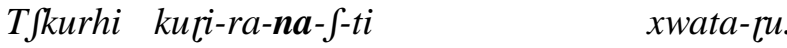

$$
\begin{aligned}
& \text { firewood burn-CAUS-PASSIV-AOR-ASS3 hill-LOC } \\
& \text { 'The firewood was burned on the hill.' (Jr) }
\end{aligned}
$$

$$
\begin{aligned}
& \text { Xwánu xorempiri-i-S-ti. } \\
& \text { John teacher-PRED-AOR-ASS3 } \\
& \text { 'John is a teacher.' (Jr) }
\end{aligned}
$$

Nevertheless, Purepecha exhibits new tendencies, in which analyticperiphrastic constructions appear. Passive (3) and equational (5) periphrastic structures adapt Purepechan morphemes to Spanish patterns without the transfer of linguistic material, which suggests that contactinduced grammaticalization processes have taken place.

The passive periphrastic construction emerges from a patient-oriented resultative participle plus $x a$ 'be there'; a verb which became an auxiliary. Evidence supporting the consideration of this construction as a remodeling of the structure (PAT) includes: a) Passive constructions involving passive participles appear in Indo-European languages, and are very rare in the Americas (Haspelmath 1994); b) the agent is introduced as an oblique complement by using the postposition ximpo (3) in the same way as the Spanish passive construction with ser, whereas this is generally impossible in the Purepecha passive derivational construction (1); c) The subject is always the patient, as in Spanish, whereas, in the derivational passive 
structure, the subject is the divalent-patient or the trivalent-recipient (Chamoreau in press); d) the younger generation use a passive periphrastic construction with the xinte 'be' copular verb (4), treated as the Spanish ser auxiliary, calquing the Spanish Aux.-Part. Order, whereas, in the passive periphrastic construction with $x a$ (3), the Purepecha Part.-Aux. order is preserved:

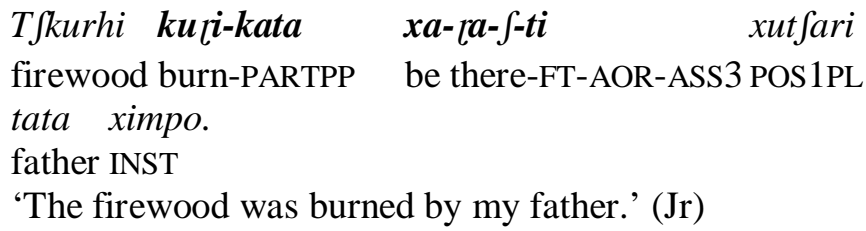

The analytic equational construction with xinte 'be' is an internallymotivated reanalysis, from a demonstrative to a 'be' verb used as a presentative (Chamoreau 2006). As a result of the influence of Spanish, many young people prefer to use the verb xinte (5) rather than use the derivational construction (2). Xinte appears essentially with nouns and pronouns. Many young people use xinte solely with adjectives (6) indicating a quality which refers to identity, and which is independent of the situation, as in 'ser' in Spanish. In (5) and (6), the Spanish SVAdj. order is a calque. This is a construction that is in opposition to the construction with $x a$ (7) which expresses a relative quality dependent on the situation, as in 'estar' in Spanish. With $x a$, the order is generally the Purepecha SAdj.V order, although it is possible to find the Spanish SVAdj. Order.

$$
\begin{array}{lll}
\text { Xwánu } & \text { xinte- }- \text {-ti } & \text { xo rempiri. } \\
\text { John } & \text { be-AOR-ASS3 } & \text { teacher } \\
\text { 'John is a teacher.' (Jr) } &
\end{array}
$$


(6) Ifu pakanta, kwhiripu miri-kwali-s-p-ti

here Pacanda people forgot-MID-AOR-PAS-ASS3

ya ima-ni at fati-ni ka myá-ntha-fa-p-ti

already DEM-OBJ man-OBJ and think-IT-PROG-PAS-ASS3

eski ima xinte-p-ka riko.

SUB DEM be-AOR/PAS-SUBJ rich

'Here in Pacanda, people had forgotten this man. They used to think that he was rich.' (Pc)

(7) Naranfa téri $\quad \boldsymbol{x a}-\boldsymbol{l a}-\int-\boldsymbol{t i}$.

orange sweet be there-FT-AOR-ASS3

'The orange is sweet.' (Jr)

\section{Nominal structures}

Changes that could have arisen through the influence of Spanish include the tendency to use the plural marker it $\int \mathbf{a}$, and the object case marker ni, with inanimate entities (8). Traditionally, the plural and object case markers are only obligatory for animate and definite entities (Villavicencio 2006).

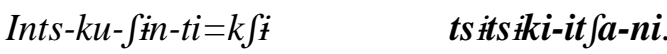

$$
\begin{aligned}
& \text { give-3APP-PROG-ASS3=3PL flower-PL-OBJ } \\
& \text { 'They used to give her flowers.' (Jr) }
\end{aligned}
$$

The Spanish diminutive suffix has become productive in Purepecha, however, only the masculine ito is used, pronounced ito or itu. Gender does not exist in Purepecha. This suffix is used with nouns, adjectives (9a), and classifiers (9b). This latter exhibits an adaptation to the Purepecha nominal phrase.

(9) a. Witsintikwa phakha-ra- - $k a=n i \quad$ xantiakhu-itu. yesterday stay-MID-AOR-ASS $1 / 2=1$ alone-DIM 'I stayed alone yesterday.' (Jr)

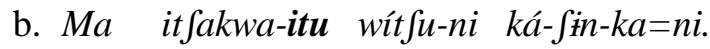
one long-DIM dog-OBJ own-HAB-ASS $1 / 2=1$

'I have one little dog.' (Jr) 


\section{Verbal structures}

There are only a few contact phenomena in the verbal structures. The most relevant of these is the transfer of the ser/estar semantic opposition (PATinfluence), being adapted as a xinte/xa dichotomy (\$3). As a result of the influence of Spanish, the constructions with the verb xinte 'be' gain a greater semblance to the Spanish construction with the verb 'ser': passive constructions (4), equational constructions (5), and attributive constructions (6). Many young speakers integrate an idiomatic expression, dejar de ser, that they have calqued from the Spanish (10):

$$
\begin{aligned}
& \text { Xorentpherakwa xurakhu-sin-ti xinte-ni ísi. } \\
& \text { education let-HAB-ASS3 be-INF thus } \\
& \text { 'The education ceased to be like that.' (Pc) }
\end{aligned}
$$

In the same way, the constructions with $x a$ 'be there' have adopted the values of the Spanish 'estar' structures: passive constructions (3), and attributive ones (7).

\section{Other parts of speech}

Purepecha shows a significant number of Spanish loans in the category 'other parts of speech'. Most loans are of the MAT type, but some cases of PAT-influence have been established within the numeral system and discourse markers.

The numeral system in Purepecha is vigesimal, and the remodeling to a decimal system is due to Spanish influence. The numbers from 1 to 6 , and 10 and 20 are generally known and used, but younger speakers prefer to use Spanish numbers except for numbers below 5. Counting and adding are generally performed using Spanish numbers. There are no contact phenomena in quantifiers.

The indefinite pronoun siempre 'always' is highly integrated, whereas other indefinite pronouns appear only occasionally. Siempre is used, with the vowel adaptation siémpri, by all generations (11), and has gained ground relative to the Purepecha indefinite pronouns mameni and menkhu, which also express time (12)

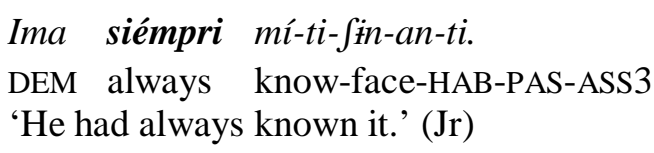


$\begin{array}{lll}n i-n t h a-\int-t i=k \int \dot{t} & y a & \text { anima-itfa } \text {. } \\ \text { go-CENTRIF-AOR-ASS3=3PL already } & \text { soul-PL }\end{array}$

'The man has bought all he will need, but (on the other hand) the souls have left.' (Jr)

Many subordinating conjunctions are borrowed from Spanish. The Spanish complementizer que, pronounced $k e$ or $k i$, is never used alone. One hypothesis suggests that $k e$ was borrowed from Spanish. Another possibility is that Purepecha also had a subordinating conjunction with the form $k i$, attested in the $16^{\text {th }}$ century. A convergence between the two elements has been favoured because they present the same form. This topic had not been studied yet. The subordinating conjunction $k e$ is employed with other borrowed markers, functioning as complex conjunctions: porki in a causal clause (17), para ke in a purpose clause (18a), sikiera ke, which is a synthetic form of the Spanish 'si quiera' in a hypothetical clause (19a), and sino ke in a contrast clause (20). These elements are analyzed as subordinating conjunctions, because they respect the Purepecha constructions; the verb of the subordinating clause is marked by subjunctive mood.

Purepecha has various subordinating conjunctions, enki, efka and efki, which seem to be being progressively replaced in these constructions by $k e$. Nevertheless, many speakers, especially those of the middle-aged and older generations, prefer to use the Purepecha ximpoki 'because' instead of porki, and to use the borrowed markers para (18b) and sikiera (19b), in combination with the Purepecha conjunctions $e \int k a$ or $e f k i$.

$$
\begin{aligned}
& \text { Ima xu-ra-jin-ti porki thu yoti-f-ka. } \\
& \text { DEM come-FT-HAB-ASS3 because } 2 \text { call-AOR-SUBJ } \\
& \text { 'He used to come because you called him.' (Jr) }
\end{aligned}
$$

$$
\begin{array}{lllll}
\text { a. Xwanu } & \text { xu- } r a-\int-t i & \text { para } & \text { ke } & \text { i } \int e-k a=r i . \\
\text { John } & \text { come-FT-AOR-ASS3 } & \text { for } & \text { SUB } & \text { see-SUBJ=2 } \\
\text { 'John came for you to see him.' (Jr) } & &
\end{array}
$$

b. Ali-Jín-ti=kini para ifki mi-ti-a-ka.

tell-HAB-ASS3=2OBJ for SUB know-face-FUT-SUBJ

'He tells you that, so that you know it.' (Jr) 
(19) a. Sikiera ke pirí-a-ka. provided SUB sing-FUT-SUBJ

'Let's hope he will sing!' (Jr)

b. Sikiera ifki tsima xu-nkwa-ka.

provided SUB DEMPL come-CENTRIP-SUBJ

'Let's hope they come back.' (Jr)

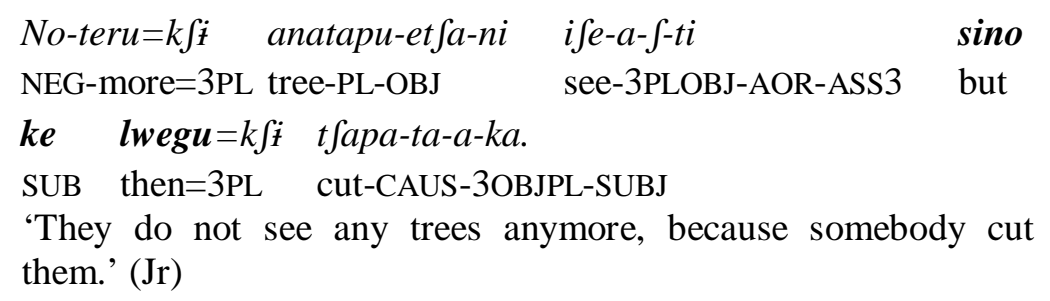

The situation of variation between the use of $k e$ or ifka/ifki in subordinating constructions is also attested with the comparative structure (see $\S 8$ ).

Generally, para is introduced in a purpose clause with para ke or para $i f k i(18 \mathrm{a}, 18 \mathrm{~b})$, however, it can also appear in a non-finite purpose construction (21).

$$
\begin{array}{lllll}
\text { Thu no } & \text { xatsi-f-ka } & \text { para } & \text { xaka-khu-ni. } \\
2 & \text { NEG } & \text { have-AOR-ASS1/2 for believe-FT-INF } \\
\text { 'You don't have to believe him.' (Jr) }
\end{array}
$$

Spanish temporal adverbializers that have been borrowed include: hasta 'until' (22), desde 'from' (23), apenas 'as soon as', pronounced apenafi (24), luego 'then' (20), and entonces 'then', generally pronounced tonses (25).

The adverbializer hasta additionally has a spatial deictic use (26). There is a native suffix of localization $t u$ (26), which has an extended function (fixed and removed localization, ablative, translative, etc.). The use of hasta allows the specification of the type of localization.

$$
\begin{aligned}
& \text { Xima khama- }- \text {-ti } \quad \text { ya ásta wéxutini. } \\
& \text { then finish-AOR-ASS3 already until year } \\
& \text { 'He had finished it by the new year.' (Jr) }
\end{aligned}
$$




$$
\text { Ántfi-kuri-Ja-ka=ni désde witsintikwa. }
$$

work-MID-PROG-ASS $1 / 2=1$ for/since yesterday

'I have been working since yesterday.' (Jr)

Petu kwhi-a-ti apenaxi thu nya-ra-ka.

Peter sleep-FUT-ASS3 as soon as 2 arrive-FT-SUBJ

'Peter fell asleep as soon as you arrived.' (Jr)

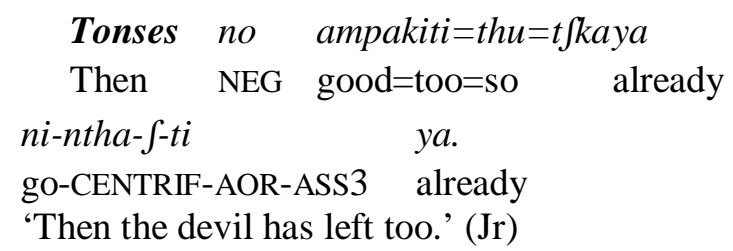

$$
\begin{aligned}
& \text { Ni-a-ka=kfï ásta xini yorekwa-ru. } \\
& \text { go-FUT-ASS } 1 / 2=1 \mathrm{PL} \text { until there river-LOC } \\
& \text { 'We will go up to the river.' (Jr) }
\end{aligned}
$$

Purepecha did not have prepositions before contact; we can assume that it was a language with only postpositions, and some suffixed case markers. So the prepositions para and por are borrowed in combination with their phrase-combining construction, i.e., they appear before the phrase or the morpheme (Chamoreau 2002b). The preposition para functions in a recipient clause (27a), and por expresses agentive (28a), causal (27a), and instrumental clauses (28a). The Purepecha postposition ximpo 'instrumental' can be used in functions similar to para (27b), or to por (28b, 29b, 30b). In all these contexts, the Purepecha marker may appear in a double construction $(27 \mathrm{c}, 28 \mathrm{c}, 29 \mathrm{c}, 30 \mathrm{c})$.
a. Ima kura-t $\int i-\int-t i=r i n i$
itfuskuta para ama-mpa. DEM ask-1/2APP-AOR-ASS3=1OBJ tortilla for mother-POSP3 'He has asked me for tortillas for his mother.' (Jr)

b. Ima kura-t $\int i-\int-t i=r i n i$ it $\int u s k u t a$ ama-mpa ximpo. (Jr)

c. Ima kura-t $\int i-\int-t i=r i n i$ it $\int u s k u t a$ para ama-mpa ximpo. (Jr) 
(28) a. Mí-ti-f-ti por ima.

know-face-AOR-ASS3 by DEM

'He knows it through him.' (Jr)

b. Mí-ti-f-ti ima ximpo. (Jr)

c. Mí-ti-f-ti por ima ximpo. (Jr)

(29) a. Tsitsiki urapiti kunti-kuri-Ja-ti por

flower white bend-REF-PROG-ASS3 under/cause

kwetsapikwa.

weight

'The white flower is bending under the weight.' (Jr)

b. Tsitsiki urapiti kunti-kuli-fa-ti kwetsapikwa ximpo. (Jr)

c. Tsitsiki urapiti kunti-kuri-Ja-ti por kwetsapikwa ximpo. (Jr)

(30)

a. Xu-ra-f-ka-ni por kamioni.

come-FT-AOR-ASS1/2-1 by bus

'I went by bus.' (Jr)

b. Xu-ra---ka-ni kamioni ximpo. (Jr)

c. Xu-ra-f-ka-n por kamioni ximpo. (Jr)

The Spanish marker komo is used in Purepecha to introduce a manner clause.

Pos $=s \dot{i} \quad$ komo maat $\int a=s \dot{i} \quad x a-r a-\int-t i$.

Thus=FOC like a man=FOC be there-FT-AOR-ASs 3

'Thus, he was there like a man.' (Jr)

The Spanish phrasal adverb ya is used to mark temporal values with two different nuances: it can introduce a completive value, generally employed with the aspect aorist or the past aorist (32), or it can express a present value (33). The story in (32) is about a vulture that has transformed himself into a woman, and the woman into a vulture. The example expresses that the vulture turned into a woman; that it was no longer an animal. In the same narrative, in (33), there is a contrast between the first verb, in the past 
tense, which indicates the state of the woman before, and the second verb, in the interrogative clause, which indicates a question about the present state, which is the state of the vulture.

$$
\begin{array}{lll}
K a & \text { mawariti-i- }-\mathrm{f}-t i & \boldsymbol{y} \boldsymbol{a} . \\
\text { and } & \mathrm{a} \text { woman-PRED-AOR-ASS3 } & \text { already }
\end{array}
$$

'And it is already a woman.' (Jr)

$$
\begin{aligned}
& \text { Thu no } \quad \text { xama- } \int-p-k a \quad \text { lísto antifi=ri } \\
& 2 \quad \text { NEG walk-AOR-PAS-ASS1/2 lively why=2 } \\
& x a-r a-\int-k i \quad y a . \\
& \text { be there-FT-AOR-INT already } \\
& \text { 'You did not used to be lively, why are you now?' (Jr) }
\end{aligned}
$$

Apart from marking temporal relations, this element $y a$ functions like a discourse marker, with the addition connector $k a$ 'and'. The latter begins a clause, while the former ends one (32).

Finally, many discourse markers are borrowed by Purepecha from the Spanish. The most frequent ones are the fillers: pues 'thus, then, well', pronounced pwes or pos (31), and bueno 'well, sure', pronounced wenu. It is also possible that as a result of the influence of Spanish, the use of the demonstrative inte 'this' is used as a filler like este in that language. This element appears in the same conditions as does inte in Spanish: it expresses a hesitation, a pause, etc. (34). It is a PAT-influence that is not connected to any direct MAT-borrowing.

$$
\begin{aligned}
& \text { Ximpoka=ni inte patsi- } n t s \dot{t}-k a=n a . \\
& \text { because }=1 \text { em be fade-head-SUBJ=EVID } \\
& \text { 'Because, em, I am bald, they said.' (Jr) }
\end{aligned}
$$

\section{Constituent order}

Constituent order seems to be influenced by areal contact prior to the $16^{\text {th }}$ century (see above, \$1), with Spanish continuing the process, and increasing it via the introduction of prepositions (while Purepecha had traditionally used postpositions).

\section{Syntax}

The organization of passive and equational constructions has been influenced by Spanish (see above $\S 3$ ). Many subordinating conjunctions 
and adverbial markers are borrowed from Spanish, in combination with the grammatical constructions they appear in, in that language.

A syntactic domain which has undergone an important reorganization due to Spanish contact is the comparison of inequality. Purepecha had traditionally utilized a comparative construction of superiority of two types (Chamoreau 1995): the exceed verb of action (35), and the combination of the exceed verb of action and a coordinated polarity construction (36):

$$
\text { pedro hatztamahati juanoni ambaqueni }
$$

(Gilberti [1558] 1987: 109)

Pedroxats-ta-ma-xa-ti xwano-ni ampake-ni.

Peter surpass-CAUS-TRANSF-PRES-ASS3 John-OBJ be good-INF 'Peter is better than John.'(Peter surpasses John in being good).

$$
\text { pedro hatztamahati ambaqueni, ca noys juan }
$$

(Gilberti 1987: 109)

Pedroxats-ta-ma-xa-ti ampake-ni $\quad k a$

Peter surpass-CAUS-TRANSF-PRES-ASS3 be good-INF and no $=\int \dot{i}$ xwano.

NEG=FOCJohn

'Peter is better than John.' (Peter surpasses with goodness and John does not).

Nowadays, there has been a reorganization as a result of a chain reaction triggered by Spanish interference. A cross-dialectal perspective shows that contact between the indigenous and Spanish constructions (the structure más...que) has brought about the emergence of nine constructions which may be classified in four different types (one type, the applicative construction, is not treated here, because it is marginal and corresponds to the derivative morphological characteristics of the language). I present here eight constructions organized in three types:

Type 1 is a borrowing or a PAT-influence of the Spanish comparative construction with borrowed degree and relator (37), with borrowed relator and the degree calque (38) or their Purepecha calques (39).

$$
\begin{aligned}
& \text { Enrike mas Sepe-s-ti } \quad \text { ke Pedru. } \\
& \text { Henry more be lazy-AOR-ASS3 SUB Peter } \\
& \text { 'Henry is lazier than Peter.' (Cn) }
\end{aligned}
$$




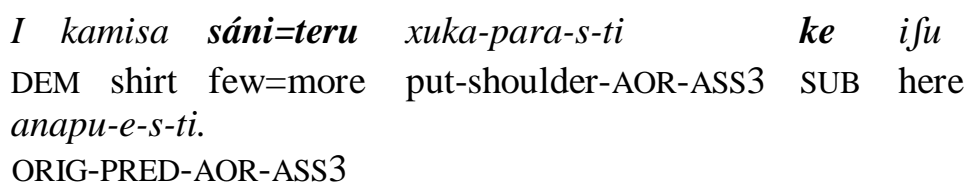

'This shirt is more expensive than those from here.' (Ih)

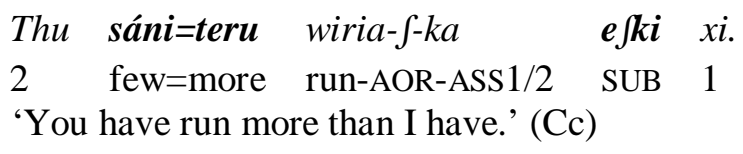

Type 2 is a mixed type, employing the Purepecha polarity construction plus the Spanish comparative degree particle mas (40) or its Purepecha calque sáni=teru (41)

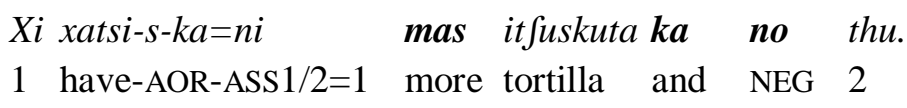

$$
\begin{aligned}
& \text { Ifu sáni=teru yó-tha-ta-fłn-ti ka no xini. } \\
& \text { here few=more long-leg-FT-HAB-ASS3 and NEG there } \\
& \text { 'Here is higher than there.' (Here is higher and there is not) (Jr) }
\end{aligned}
$$

Type 3 is a hybrid type, employing the Spanish degree mas plus the relator $k e$, and a locative construction with the Spanish preposition 'de' (42), which represents an instance of code-mixing, because it only appears in a few expressions, and never alone (the Spanish preposition de 'of' appears in this context of comparative constructions and in some expressions, for example de veras 'sure'). This new hybrid locative construction does not occur either in Spanish or in traditional Purepecha. This construction can occur with the Purepecha degree calque sáni=teru (43):

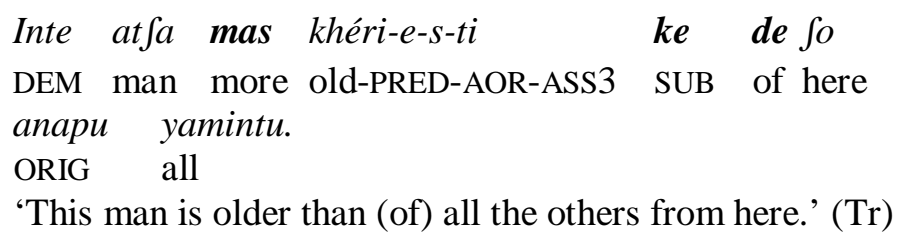

'This man is older than (of) all the others from here.' (Tr) 


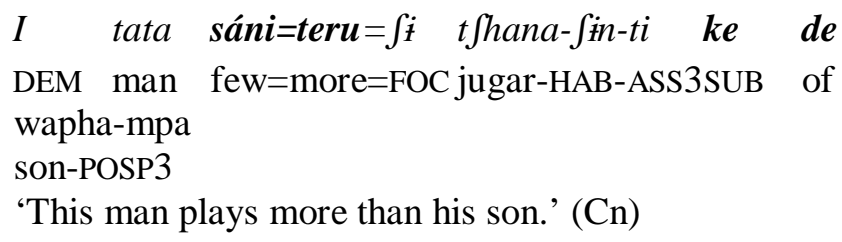

This hybrid construction may also occur with the Spanish preposition entre. In (44), we can observe the presence of the borrowed marker of degree más before the quality, and the comparative relator $k e$, which is followed by the Spanish preposition entre.

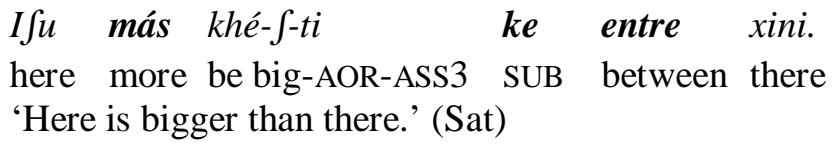

Finally, it is unclear whether Purepecha has ever had a comparative construction of inferiority. In order to express this domain, Purepecha employs two strategies: a) to use the borrowed Spanish comparative construction of superiority with the negation, employing either the Purepecha relator (45a) or Spanish relator (45b), and b) to borrow the Spanish construction with the Spanish degree menos (pronounced menu $₫ \dot{z}$ in certain varieties), and the Purepecha calque relator eska (46), or the borrowed degree and relator (47).

a. Maria sáni=taru no wipapi-f-ti eski thu.

Maria few=more NEG be strong-AOR-ASS3 SUB 2

'Maria is weaker (less strong) than you are.' (Maria is not stronger than you are) (Ar)

b. Maria sáni=taru no winapi-f-ti ke thu. (Oc)

Selia menos yó-tha-la-jin-ti eska $=n i$.

Celia less long-leg-FT-HAB-ASS3SUB $=1$

'Celia is shorter (less tall) than I am.' (Cm)

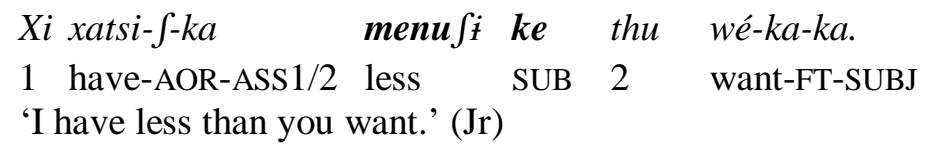




\section{Conclusion}

The grammatical MAT-loans are numerous, and appear within their Spanish grammatical constructions. A relevant phenomenon is the typological profile of Purepecha, which shows new tendencies.

Purepecha is a synthetic-agglutinative language, and, nowadays, new analytic-periphrastic constructions appear, without modifying its elaborate morphological system, but revealing a structural rapprochement to the Spanish passive and equational constructions: two distinct structures (a morphological one and a periphrastic one) may simultaneously perform the same function. Purepecha is exhibiting language-internal grammaticalization processes to replicate Spanish models.

There are PAT-influences that are not connected to any direct MATborrowing. Other PAT-influences are the comparative constructions, linked to MAT-borrowing in some varieties, and showing only pattern reduplication in others.

$\begin{array}{ll}\text { Abbreviations } \\ \text { AOR } & \text { aorist } \\ \text { APP } & \text { applicative } \\ \text { ASS } & \text { assertive } \\ \text { CAUS } & \text { causative } \\ \text { CENTRIF } & \text { centrifuge } \\ \text { CENTRIP } & \text { centripetal } \\ \text { COM } & \text { comitative } \\ \text { DEM } & \text { demonstrative } \\ \text { DIM } & \text { diminutive } \\ \text { EVID } & \text { evidential } \\ \text { FOC } & \text { focus } \\ \text { FT } & \text { formative } \\ \text { FUT } & \text { future } \\ \text { HAB } & \text { habitual } \\ \text { INF } & \text { infinitive } \\ \text { INST } & \text { instrumental } \\ \text { INT } & \text { interrogative } \\ \text { IT } & \text { iterative } \\ \text { LOC } & \text { locative } \\ \text { MID } & \text { middle } \\ \text { NEG } & \text { negation } \\ \text { OBJ } & \text { object } \\ \text { ORIG } & \text { origin } \\ \text { PARTPP } & \text { patient-oriented participle } \\ & \end{array}$




$\begin{array}{ll}\text { PAS } & \text { past } \\ \text { PASSIV } & \text { passive } \\ \text { PL } & \text { plural } \\ \text { POS } & \text { possessive } \\ \text { POSP } & \text { kinship possessive } \\ \text { PRED } & \text { predicativizator } \\ \text { PROG } & \text { progressive } \\ \text { REF } & \text { reflexive } \\ \text { RES } & \text { residential } \\ \text { SUB } & \text { subordinating conj. } \\ \text { SUBJ } & \text { subjunctive } \\ \text { TRANSF } & \text { transference }\end{array}$

\section{Communities}

$\begin{array}{ll}\mathrm{Ar} & \text { Arantepacua } \\ \mathrm{Cc} & \text { Cocucho } \\ \mathrm{Cm} & \text { Comachuén } \\ \mathrm{Cn} & \text { Cuanajo } \\ \mathrm{Ih} & \text { Ihuatzio } \\ \mathrm{Jr} & \text { Jarácuaro } \\ \mathrm{Oc} & \text { Ocumicho } \\ \mathrm{Pc} & \text { Pacanda } \\ \mathrm{Sat} & \text { San Andres Tzirondaro } \\ \mathrm{Tr} & \text { Tirindaro }\end{array}$

\section{References}

Capistran Alejandra

2002 Variaciones de orden de constituyentes en p'orhépecha. Topicalización y focalización. In Paulette Levy (ed.), Del Cora al Maya Yucateco. Estudios lingüísticos sobre algunas lenguas indígenas mexicanas. 349-402. México: UNAM..

Chamoreau, Claudine

2002a Le système phonologique du purepecha. Une étude en synchronie dynamique. Travaux du SELF IX: 133-161.

2002b Dinámica de algunos casos en purepecha. In: Zarina Estrada Fernández and Rosa Maria Ortiz Ciscomani (eds.), VI Encuentro Internacional de Lingüística en el Noreste, 271-290. Hermosillo: Unison. 
2005 Dialectología y dinámica : reflexión a partir del purépecha. In: Claudine Chamoreau (Coord.), Trace 47 : Dinámica lingüística, 61-81. México: CEMCA.

2006 En busca de un verbo "ser" en purépecha. Cadena de gramaticalización y gramaticalización en cadena. In: Rosa Maria Ortiz Ciscomani (ed.), VIII Encuentro Internacional de Lingüística en el Noreste, 65-84. Hermosillo: Unison.

2007 Looking for a new participant. Passive in Purepecha. In: Zarina Estrada Fernández, Soren Wichmann, Claudine Chamoreau, and Albert Álvarez González (eds.), Studies in Voice and Transitivity. Munich: Lincom.

Gilberti, Maturino

1987 Reprint. Arte de la lengua de Michoacán. Morelia: Fimax. Original edition, Mexico: Juan Pablo Impresor, 1558.

Haspelmath, Martin

2004 Passive Participles across Languages. In: Barbara Fox and Paul Hopper (eds.), Voice: Form and Function, 151-177. Amsterdam/Philadelphia: John Benjamins Publishing Company.

Villavicencio, Frida

2006 P'orhépecha kaso sïrátahenkwa: desarrollo del sistema de casos del purépecha. México: CIESAS-COLMEX. 